\title{
Assessment of Carbon Metabolism of Cherry Tomato Fruits: How Does Affects Potassium Biofortification During Crop Cycle at Postharvest Storage?
}

\author{
Christian Constan-Aguilar \\ Luis Romero \\ Begona Blasco \\ Juan Manuel Ruiz \\ Department of Plant Physiology, Faculty of Science, \\ University of Granada, Granada, SPAIN
}

Teresa Soriano

Department of Agricultural Production, Institute of Research and Training in Agriculture and Fisheries (IFAPA), Granada, SPAIN

doi: 10.19044/esj.2016.v12n15p44 URL:http://dx.doi.org/10.19044/esj.2016.v12n15p44

\begin{abstract}
In the present work, we evaluate the implementation of a $\mathrm{K}$ biofortification programme that increases the dose of this macronutrient in the nutrient solution for growing tomatoes. The aim is assess whether this treatment improves the response of fruits to postharvest for 21 days at $4^{\circ} \mathrm{C}$. Three $\mathrm{K}$ treatments were applied during the crop cycle of the plants: 5, 10, and $15 \mathrm{mM}$ of $\mathrm{KCl}$. The enzymes involved in carbon metabolism and sugar concentration were studied, both on the day of harvest and after 21 days of storage in cold room at $4^{\circ} \mathrm{C}$. Similarly, enzymes related to the metabolism of organic acids as well as their concentration were studied. The application of this supplement, aside from increasing $K$ concentration in the fruits, stimulated the sucrose (Suc) degradation by sucrose synthase (SuSy) activity while increasing fructose (Fruc) and glucose (Gluc) as well as raising malate accumulation induced by the activity of PEPC and MDH enzymes during storage of 21 days at $4^{\circ} \mathrm{C}$. The $\mathrm{KCl}$ treatments could be related to changes in carbon metabolism and suggest a protective role against cold storage, improving the quality of tomato fruits.
\end{abstract}

Keywords: Carbon metabolism, postharvest, potassium biofortification, tomato fruit 


\section{Introduction}

Tomato (Solanum lycopersicum L.) is an annual horticultural plant with a broad worldwide distribution and enormous economic value, while its high content in antioxidant compounds offers a number of health benefits to the consumer (Bilton and al, 2001). Tomatoes benefit human health by their high contents in phytonutrients such as lycopene, $\beta$-carotene, phenolic compounds, ascorbic acid, and essential nutrients, which can detoxify reactive oxygen species (ROS) and prevent oxidative changes in the human body (García-Closas and al, 2004). For all this, the content of these compounds is critical for assessing the quality of the fruit.

Other characteristics that determine tomato quality are related to the organoleptic properties, defined by a number of physico-chemical parameters that make the fruit satisfactory to the consumer. Numerous works have revealed that organoleptic parameters such as flavour are key components for selling the tomato (Gough and Hobson, 1990; Causse and al, 2002). The most important parameter for organoleptic quality of tomato fruits is flavour, produced mainly by a combination of sugars and organic acids, which implies that the level of concentration of both compounds can significantly affect consumer acceptance (Salles and al, 2003). Sugars and organic acids are the main metabolites in tomato fruits and constitute over $60 \%$ of the dry matter (Davies and Hobson, 1981). They not only contribute to the soluble solids but are also essential to the flavour intensity. Balanced and high levels of sugars and organic acids are important for the perception of a high-quality fruit (Bucheli and al, 1999; Lobit and al, 2003). Nevertheless, the choice of the tomato cultivar, the cultivation technique, and the postharvest tasks are applied primarily to reducing the loss of crop yield and do not give priority to the effect that these practices have on organoleptic characteristics.

Tomato, a very perishable climacteric fruit, requires the use of preservation technologies to slow the ripening process that occurs after harvest in order to maintain its quality and extend its shelf life. Tomato-fruit sugar content is the result of fruit physiological, metabolic, and genetic processes that are under developmental control (Baldet and al, 2006; Mounet and al, 2009; Wang and al, 2009). Generally, the tomato fruit accumulates sugars in the form of sucrose or reducing sugars (glucose and fructose), depending on the environmental conditions and on the growth phase of the plant (Gomez and al, 2009). Although sucrose is the main form of sugar translocated in tomato plants, glucose and fructose are generally present in quantities equal to or greater than sucrose in tomato fruits. Two pathways for sucrose breakdown provide the basis for a flexible system that can markedly affect the partitioning and metabolism of assimilated carbon in sink tissues (Geiger and al, 1996). Sucrose synthase located in the cytosol catalyses a 
reversible reaction that degrades sucrose and UDP to UDP glucose and fructose, while acid (apoplast or vacuole) and neutral (cytosol or vacuole) invertase catalyse the hydrolysis of sucrose to glucose and fructose. These sucrolytic activities serve sink tissues in plants in the primary step of converting sucrose into sink-storage products, such as starch, proteins, and oil (Doehlert and Chourey, 1991; Balibrea and al, 1996; Rosales and al, 2007).

Organic acid content is regarded as one of the most important quality traits of fresh tomato. The acidic taste in tomato is attributed mainly to citric acid and malic acid, which corresponds to over $90 \%$ of the organic acids in tomato (Davies and Hobson, 1981; Schauer and al, 2005). However, the complexity of carboxylic acid metabolism and storage means that it is difficult to predict the best way to engineer altered carboxylic acid levels. Carboxylic acids constitute a major component of the osmotic potential that drives cell expansion through water uptake in the expansion phase of fruit growth (Liu and al, 2007). The concentrations of citrate and other carboxylic acids fall during this expansion phase as the cell contents are diluted (Baxter and al, 2005; Carrari and al, 2006). However, during the final stages of ripening, the level of citrate (and to a lesser extent other carboxylic acids) increases again such that it is present at high abundance in the ripe fruit. The complexity of this cycle is reflected in the range of enzymes that have been proposed to control fruit citrate and malate accumulation, including phosphoenolpyruvate carboxylase (Guillet and al, 2002), citrate synthase (Sadka and al, 2000), and malate dehydrogenase. The activity of these enzymes determines the synthesis and accumulation of these organic acids. The maximal catalytic activities of enzymes of the tricarboxylic acid cycle (TCA) generally decline during fruit development, and there are no pronounced changes in activities during the later stages of ripening that correlate with the rise in organic acid levels (Steinhauser and al, 2010).

Postharvest storage, handling and distribution of fruit at low temperatures is the most common and manageable approach to control ripening and subsequent deterioration and to maximize product shelf life. However, tomatoes, like many other subtropical fruits, are susceptible to develop symptoms of chilling injury, a physiological disorder caused by the exposure to low temperatures above the freezing point. The effect that postharvest cold has on the organoleptic properties (organic sugar-acid relation) in fruits has been investigated in the following works. GonzálezAguilar and al (2004), working with guava fruits and methyl jasmonate (MJ) treatments, stored red and white cultivars of guava fruits at $5^{\circ} \mathrm{C}$ for up to 15 days plus two days at $20^{\circ} \mathrm{C}$ and found that $\mathrm{MJ}$ treatments reduce the chilling injury (CI) index and increased sugar content. These authors concluded that $\mathrm{MJ}$ reduces chilling injury and activates the fruit-defence response. Later, 
Gómez and al (2009), studying tomato fruits, showed that cold storage retarded the accumulation of simple sugars in fruits. In ripe red fruits, the fructose level increased both during storage at $20^{\circ} \mathrm{C}$ and at $6^{\circ} \mathrm{C}$. With respect to glucose, its content increased at $20^{\circ} \mathrm{C}$, while it decreased significantly during the first $18 \mathrm{~h}$ of chilling treatment, recovering later to levels that were somewhat higher than initial values. In addition, these authors found that cold storage slowed the metabolism of organic acids in tomato fruits. Each organic acid showed a different pattern in normally ripening fruits. While tartaric, malic, ascorbic, and citric acid tended to show modest but significant decreases during ripening, the levels of succinic acid slowly built up. These trends seem not to have been affected by the chilling treatment, which slowed but did not halt the specific kinetics of most acids. Farneti and al (2010) after 5 days of $4^{\circ} \mathrm{C}$ storage, tomatoes generally showed depressed sugar and boosted the acid content (especially in cocktail tomatoes) compared to $15^{\circ} \mathrm{C}$ stored fruit, indicating a loss of sensorial quality at $4^{\circ} \mathrm{C}$. Sánchez-Bel and al (2012), in peppers, found that the ones submitted to cold stress presented higher concentrations of sucrose and fructose, while glucose was not appreciably affected. With regard to the organic acid concentration, citric acid declined in concentration while malic acid augmented. The comparative proteomic analysis between control and chilled fruits revealed that the main alterations induced by CI in bell pepper fruits are linked to redox homeostasis and carbohydrate metabolism. Finally, in this sense, Cao and al (2013) studying loquat fruits stored in a cold chamber, examined the relationship between chilling injury and sugar metabolism. Chilling-resistant 'Ninghaibai' fruit had higher levels of glucose and fructose and higher activities of sucrose-hydrolysing enzymes, such as sucrose synthase-cleavage and invertase, than did 'Dahongpao' (sensitive). Furthermore, the chillingresistant 'Ninghaibai' fruit also showed higher activities of hexokinase and fructokinase, involved in hexose phosphorylation and sugar signal generation. These results suggest that the higher content of hexoses and activities of hexose sensors were likely part of the mechanism for chilling tolerance of loquat fruit.

One of the factors that can a priori improve cold tolerance in fruit is the presence of high potassium $(\mathrm{K})$ concentrations. In this sense, Beringer and Trolldenier (1980) indicated that a high $\mathrm{K}$ concentration in cells can improve cold tolerance by lowering the osmotic potential Later works have revealed a positive correlation between $\mathrm{K}$ availability and cold-stress tolerance, revealing, furthermore, that suboptimal K concentrations intensify the negative effects of cold stress (Kafkafi, 1990; Yermiyahu and Kafkafi, 1990). In addition, significant yield losses and extensive leaf damage due to cold temperatures reportedly occurred under low $\mathrm{K}$ fertilization, while the effects were alleviated once the $K$ supply was increased in a number of 
vegetable crops such as potato (Solanum tuberosum L.) and tomato (Lycopersicon esculentum Mill.) (Hakerlerler and al, 1997). This could be due to the effect of $\mathrm{K}$ on sugar accumulation and the essential role that this physiological process plays in the resistance to chilling injury in plants. Javaria and al (2012) in their investigations with different rates of K fertilizer in relation to chemical and sensory attributes of tomato, observed that total solids, sugars, and titratable acidity increased significantly with higher rates of $\mathrm{K}$. It was concluded that increasing the $\mathrm{K}$ concentrations improved the quality of tomato fruit parameters. Similar results were found by Han and al (2012) on applying $\mathrm{K}$ at different growth phases in tomato plants. These authors found an increase in soluble sugar, while soluble sugar, organic acid, and soluble solids were the highest among all the treatments (increases of 44.7\%, 28.8\% and $7.1 \%$ as compared with control treatment, respectively). Potash applied during the fruit-growth phase reached the highest ratio of sugar to acid.

In view of the above-mentioned functions of $\mathrm{K}$ in fruit quality, the aim of the present study was to examine how the application programme of biofortification with different application rates of $\mathrm{K}$ in the form of $\mathrm{KCl}$ influences the $\mathrm{C}$ metabolism of cherry tomato (Solanum lycopersicum L. cV. AsHiari) fruits and therefore their organoleptic properties after storage for 21 days in a cold chamber at $4^{\circ} \mathrm{C}$. In addition, whether the metabolism of sugars and organic acids is determinant in the resistance to chilling injury was evaluated.

\section{Materials and Methodology \\ Plant material, growth conditions and Sampling ot tomato fruits}

Seeds of cherry tomatoes (Solanum lycopersicum L. cV. AsHiari grafted on cv. Maxifort rootstock) were sown in flat trays (cell size $3 \mathrm{~cm} \mathrm{x} 3$ cm x $10 \mathrm{~cm}, 100$ cells per tray) filled with 50\% [v/v] perlite-peat mixture, and kept under greenhouse conditions for 5 weeks. Subsequently, the seedlings were transplanted to an experimental greenhouse at La Nacla Experimental Station (Motril), near the Granada coast in southern Spain $\left(36^{\circ}\right.$ $45^{\prime} \mathrm{N}$; $3^{\circ} 30^{\prime} \mathrm{W}$; altitude $130 \mathrm{~m}$ ). The “parral” greenhouse consisted of three modules having a symmetrical gable roof with a slope of $27^{\circ}$ and having an E-W longitudinal orientation (Soriano and al, 2004; Constán-Aguilar and al, 2015). The active environmental control was limited to a heating system by hot-air generators, and a natural ventilation system through wall and roof windows. In the greenhouse, the cladding material was a multilayer film 0.2 mm thick, with a layer of ethylene-vinyl-acetate between two layers (inner, antidrop; and outer, long life) of low-density polyethylene. The plants were grown in 40-L perlite B-12-filled sacks (1.20 m long) spaced $0.5 \mathrm{~m}$ apart in rows $1.4 \mathrm{~m}$ apart. With 3 tomato plants per sack and 2 stems per plant, the 
planting scheme was 3.21 plants $\mathrm{m}^{-2}$. Their arrangement in the greenhouse was in 12 rows with North-South orientation. The statistical design was on randomized block. Other growing conditions such as irrigation and fertilization followed (Soriano and al, 2004; Constán-Aguilar and al, 2015). The different treatments applied were: $5 \mathrm{mM} \mathrm{KCl,} 10 \mathrm{mM} \mathrm{KCl} \mathrm{y} 15 \mathrm{mM}$ $\mathrm{KCl}$ as liquid solution from the beginning to the end of the experiment.

The cherry tomato crop cycle lasted from October to May (230 days), with a complete truss of tomatoes (10-12 tomatoes per truss) maturing every 10 days. Cherry tomato fruits were sampled in February at 140 days after transplanting (DAT). Uniformly ripe healthy fruits, at the red-ripe stage, were harvested. Approximately 200 tomato fruits from each treatment were randomly collected (discarding the green fruits at the end of the truss) and were rinsed three times in distilled water after disinfection with $1 \%(\mathrm{v} / \mathrm{v})$ Triton X-100 (Wolf 1982), and then blotted on dry filter paper.

\section{Biomass parameters}

From 180 tomatoes harvested from each treatment, 90 tomatoes were intended for analysis at harvest day (T0) being clustered in 9 replicates of 10 fruits. 5 tomato fruits from each replicate were weighed obtaining fresh weight (FW) and then were dried in a lyophilizer to determine the dry weight (DW) and percentage of dry matter (\% DM). Another 5 tomato fruits from each replicate were homogenized, and these samples of fresh tissues were stored at $-80^{\circ} \mathrm{C}$. For analyzing the fruits after 21 days of storage in a cold room at $4^{\circ} \mathrm{C}$ (T21), in the same way, 90 tomatoes were intended for analysis being clustered in 9 replicates of 10 fruits. 5 tomato fruits from each replicate were weighed obtaining FW at (T0) and stored 21 days in a cold room at $4^{\circ} \mathrm{C}$, after this period were reweighed (T21), and then were dried in a lyophilizer to determine the DW and \% of DM. Another 5 tomato fruits from each replicate were homogenized, and these samples of fresh tissues were stored at $-80^{\circ} \mathrm{C}$. Samples of fresh and dry tissues from the cherry tomato fruits were used to analyse the parameters described below.

For the determination of the percentage of lost of fresh weight (\% LFW), the following formula was used for each treatment:

\% LFW= (FW T0- FW T21)*100/FW T0

To calculate percentage of dry matter (\% DM) was followed the method proposed by Garg and Cheema (2011). Some tomatoes were weighed and then lyophilized for $72 \mathrm{~h}$. After freeze drying, the samples are reweighed. The\% DM was calculated as:

$\mathrm{DM}(\%)=(\mathrm{B} / \mathrm{A}) \times 100$

Where $\mathrm{A}$ is the total fresh weight of sample (g), and $\mathrm{B}$, the total weight of dry sample (g). 


\section{Determination of $K$ concentration}

For the determination of $\mathrm{K}$ concentration, $0.2 \mathrm{~g}$ of dry cherry tomato fruits were ground and mineralised by wet digestion with $\mathrm{H}_{2} \mathrm{SO}_{4} 12 \mathrm{M}$ and $\mathrm{H}_{2} \mathrm{O}_{2}$ at $30 \%$ and $\mathrm{P}$ free, at a temperature of $275-300{ }^{\circ} \mathrm{C}$. After this step were added $20 \mathrm{~mL}$ of deionised $\mathrm{H}_{2} \mathrm{O}$, and finally $\mathrm{K}$ concentration was analysed by flame photometry (Wolf, 1982).

\section{Sugars metabolism}

For extraction of sucrose synthase (EC 2.4.1.13), a quantity of $0.2 \mathrm{~g}$ of tomato fruits were homogenized in $1 \mathrm{ml}$ of buffer Heppes-HCl $50 \mathrm{mM}$, $\mathrm{pH} 7.5$, which contained: magnesium chloride $0.5 \mathrm{mM}$, sodium EDTA 1 $\mathrm{mM}$, DTT $2.5 \mathrm{mM}$, Triton X-100 at $0.05 \%$, based on the method of Cheikh and Brenner (1992). The homogenate was filtered and centrifuged at $12000 \mathrm{~g}$ for $10 \mathrm{~min}$. The determination of the SuSy activity followed the method of Kerr and al (1984). The reactions were started by the addition of an aliquot of $100 \mu \mathrm{L}$ of the leaf extract previously centrifuged in a reaction buffer adapted from Cheikh and Brenner (1992), composed of sodium Heppes 50 $\mathrm{mM}$ (pH 7.5) that contained: $\mathrm{MgCl} 15 \mathrm{mM}$, fructose-6-phosphate (F-6-P) 25 $\mathrm{mM}$, UDP-G $25 \mathrm{mM}$, Potassium fluoride (FK) $10 \mathrm{mM}$. The absorbance was measured at $520 \mathrm{~nm}$ against a standard sucrose curve.

Acid (EC 3.2.1.25) and neutral (EC 3.2.1.26) invertases were extracted in $\mathrm{KH}_{2} \mathrm{PO}_{4}-\mathrm{K}_{2} \mathrm{HPO}_{4}$ buffer $(0.2 \mathrm{M}, \mathrm{pH} 7.0)$ and $(20 \mathrm{mM}) 2-$ mercaptoethanol, as described by Hubbard and al (1989). The extracts were assayed for acid invertase by addition of $30 \mu \mathrm{L}$ enzyme preparation to test tubes containing $600 \mu \mathrm{L}$ sodium acetate buffer $(0.1 \mathrm{M}, \mathrm{pH} 4.5)$ and $200 \mu \mathrm{L}$ sucrose $(0.75 \mathrm{M})$ equilibrated in a $37^{\circ} \mathrm{C}$ water bath. The reaction was allowed to proceed for $30 \mathrm{~min}$ and was stopped by addition of $1 \mathrm{~mL}$ dinitrosalicylic acid reagent. After that, being incubated for $5 \mathrm{~min}$ at $100^{\circ} \mathrm{C}$ and allowed to cool to room temperature. Finally was added $1 \mathrm{~mL}$ of Rochelle salt at $40 \%$. The absorbance was measured at $575 \mathrm{~nm}$ against a standard glucose curve. Neutral invertase activity was determined as described above, except that Na-acetate buffer $(0.1 \mathrm{M}, \mathrm{pH} 4.5)$ was substituted for $\mathrm{K}_{2} \mathrm{HPO}_{4}$-citrate buffer (0.1 M, pH 7.0) (Hubbard and al, 1989).

\section{Organic acids metabolism}

Extracts for measuring enzyme activities tomato fruit $(0.2 \mathrm{~g})$ was homogenized with $1 \mathrm{ml}$ of extraction buffer containing $30 \mathrm{mM}$ sorbitol, 1\% bovine serum albumin (BSA) and 1\% polyvinylpyrrolidone (PVP) in 100 $\mathrm{mM}$ N-2-hydroxyethylpiperazine- N\%-2-ethanesulphonic acid (HEPES)$\mathrm{KOH}, \mathrm{pH}$ 8.0. The slurry was centrifuged for $15 \mathrm{~min}$ at $10.000 \mathrm{~g}$ and $4^{\circ} \mathrm{C}$, and the supernatant was collected and analysed immediately. The activities of all enzymes were analysed in $1 \mathrm{ml}$ (final volume) of the media indicated 
below. Malate dehydrogenase (MDH; EC 1.1.1.37) activity was determined with oxalacetate as substrate (Dannel and al, 1995) by measuring the decrease in absorbance at $340 \mathrm{~nm}$ due to the enzymatic oxidation of NADH. The reaction was carried out with $70 \mu \mathrm{L}$ of extract in $0.1 \mathrm{mM}$ NADH, 0.4 $\mathrm{mM}$ oxalacetate and $46.5 \mathrm{mM}$ Tris- $\mathrm{HCl}, \mathrm{pH}$ 9.5. Citrate synthase (CS; EC 4.1.3.7) was assayed spectrophotometrically according to Srere (1967) by monitoring the reduction of acetyl coenzyme A (CoA) to CoA with 5-5\%dithio-bis-2-nitrobenzoic acid (DTNB) at $412 \mathrm{~nm}$. The reaction was carried out with $50 \mathrm{ml}$ of extract in $0.1 \mathrm{mM}$ DTNB, $0.36 \mathrm{mM}$ acetyl CoA, $0.5 \mathrm{mM}$ oxalacetate and $100 \mathrm{mM}$ Tris- $\mathrm{HCl}, \mathrm{pH}$ 8.1. Phosphoenol pyruvate carboxilase (PEPC; EC 4.1.1.31) activity was measured in a coupled enzymatic assay with MDH according to López-Millan and al (2001) with 70 $\mu \mathrm{L}$ of extract in $2 \mathrm{mM}$ phosphoenol pyruvate (PEP), $10 \mathrm{mM} \mathrm{NaHCO}, 5 \mathrm{mM}$ $\mathrm{MgCl}_{2}, 0.16 \mathrm{mM} \mathrm{NADH}$ and $100 \mathrm{mM}$ N,N-bis[2-hydroxyethyl]glycine (Bicine)-HCl, pH 8.5.

\section{Sugars and organic acids content}

Hexose (glucose and fructose) and sucrose contents were extracted and quantified using a kit (Roche Biopharm, St Didier au Mont d’Or, France) based on enzyme-linked formation of nicotinamide adenine dinucleotide phosphate (NADPH).

The determination of organic acids was based on the method of Scherer and al (2012) with slight modifications and was performed using HPLC with a DAD UV-visible detector (Agilent Technologies, USA) under the following conditions: Phenomenex reverse-phase column, $250 \times 4.6 \mathrm{~mm}$ i.d., $5 \mu \mathrm{m}$, Li-Chrospher $100 \mathrm{RP}-18$, with a $4 \times 4 \mathrm{~mm}$ i.d. guard column of the same material (Luna, Phenomenex, Utrecht, Belgium). About $0.2 \mathrm{~g}$ of freeze-dried tomato samples were homogenized with $\mathrm{H}_{2} \mathrm{O}$ milliQ. The resulting mixture was centrifuged for $400 \mathrm{~g} 2 \mathrm{~min}$ and then filtered through a $0.45 \mu \mathrm{m}$ membrane filter, and triplicates of $10 \mathrm{ml}$ for each sample were analysed by HPLC-DAD. HPLC analysis of organic acids was carried out using the same equipment as described above. Samples were injected into an ACE 5C18 column, $250 \times 4.6 \mathrm{~mm}$ (HICHROM) operating at $25^{\circ} \mathrm{C}$. A single mobile phase consisting of $0.01 \mathrm{M}$ of $\mathrm{KH}_{2} \mathrm{PO}_{4}(\mathrm{pH} 2.6)$ at $0.5 \mathrm{ml} / \mathrm{min}$ was used. The elution was monitored at $210 \mathrm{~nm}$. Malic and citric acid was used as a standard (SIGMA-ALDRICH), eluting at $7.27 \mathrm{~min}$ and $10.57 \mathrm{~min}$ respectively.

\section{Sweetness index}

The sweetness index of fruits, an estimate of total sweetness perception, was calculated, based on the amount and sweetness properties of individual carbohydrates (Keutgen and Pawelzik, 2008). The contribution of 
each carbohydrate was calculated, based on the fact that fructose is 2.30 and sucrose 1.35 times sweeter than glucose and, hence, the sweetness index was calculated as $(1.00$ [glucose] $)+(2.30$ [fructose] $)+(1.35$ [sucrose] $)$.

\section{Statistical analysis}

Data were analysed using one-way analysis of variance (ANOVA) to determine significance and Fisher's protected least significant difference (LSD) test to separate means. Standard errors of the means were also calculated. The significance levels were expressed as $* P<0.05$, ** $P<0.01$, *** $P<0.001$, and ns (not significant) $P>0.05$.

\section{Results and Discussion}

\section{Biomass parameters and $K$ concentration}

The postharvest water loss from fresh products is a major problem because it provokes the weight loss, most products becoming unsellable as fresh products after losing 3-10\% of their weight (Ben-Yehoshua and Rodov, 2003). In all the treatments, after 21 days of storage in a cold chamber, the FW decreased (Figure 1), although with the treatment $15 \mathrm{mM} \mathrm{KCl}$ the loss was less than in the rest of the treatments, with only $6 \%$ with respect to T0 $(P<0.001$, Figure 1). For the treatments 5 and $10 \mathrm{mM} \mathrm{KCl}$ the loss of $\mathrm{FW}$ at T21 was 17 and 18\%, respectively, in relation to T0. In the present work, the fruits harvested from the plants treated with $15 \mathrm{mM} \mathrm{KCl}$ at T21 presented a lower percentage of LFW (6\%) (Figure 2) while the treatments 5 and $10 \mathrm{mM}$ $\mathrm{KCl}$ showed a LFW percentage of $17 \%$ and $18 \%$, respectively (Figure 2), the treatment $15 \mathrm{mM} \mathrm{KCl}$ improving the postharvest response $(P<0.001$, Figure 2 ). These results suggest that the application of the highest $\mathrm{K}$ rate in $\mathrm{KCl}$ form prevents weight and water loss during postharvest storage. In this context, Almeselmani and al (2010) observed that an extra provision of $\mathrm{K}$ in the fertilization of tomato plants can help to preserve fruits during storage.

Figure 1: Effect of $\mathrm{KCl}$ treatments at the day of harvest over FW in cherry tomato fruits. Values are means $(n=9)$ and differences between means were compared by Fisher's least-significant difference test of (LSD, $p=0.05$ ). Means followed by the same letter do not differ significantly.

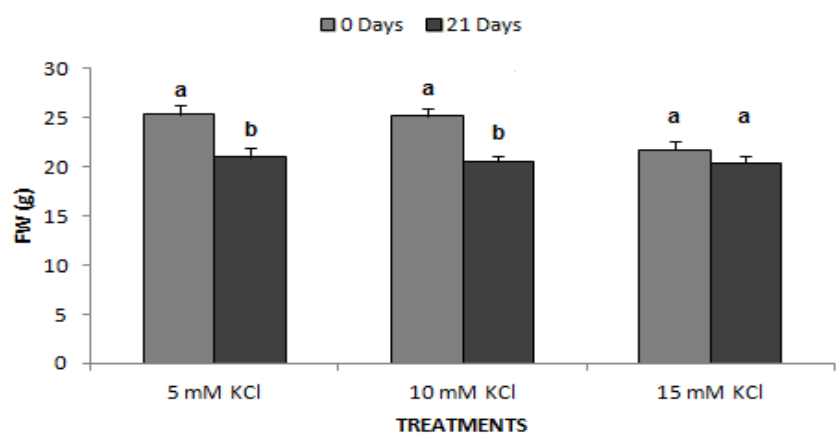


Figure 2: Effect of $\mathrm{KCl}$ treatments at the day of harvest over \% LFW in cherry tomato fruits. Values are means $(n=9)$ and differences between means were compared by Fisher's leastsignificant difference test of (LSD, $p=0.05$ ). Means followed by the same letter do not differ significantly.

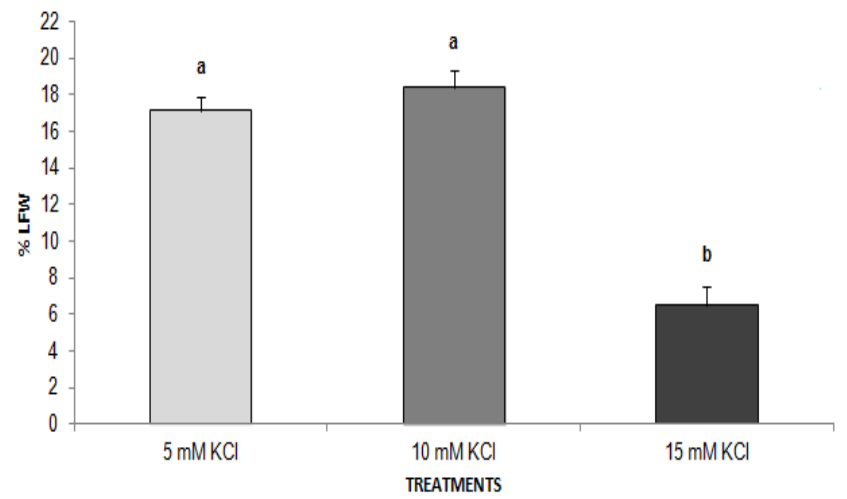

Finally, with respect to the $\mathrm{K}$ concentrations at harvest, in the present experiment, a proportional response was observed in relation to the $\mathrm{KCl}$ rate applied, and the highest concentration was registered in the fruits from plants grown with the rate of $15 \mathrm{mM} \mathrm{KCl}(P<0.001$, Figure 3$)$. These results demonstrate the validity of the biofortification programme with $\mathrm{K}$ in tomato plants, since the consumption of fruits treated with $15 \mathrm{mM} \mathrm{KCl}$ provide added intake of this macronutrient, this being a potential benefit to human health (He and MacGregor, 2008).

Figure 3: Effect of $\mathrm{KCl}$ treatments at the day of harvest over concentration of K cherry tomato fruits. Values are means $(n=9)$ and differences between means were compared by

Fisher's least-significant difference test of (LSD, $p=0.05$ ). Means followed by the same letter do not differ significantly.

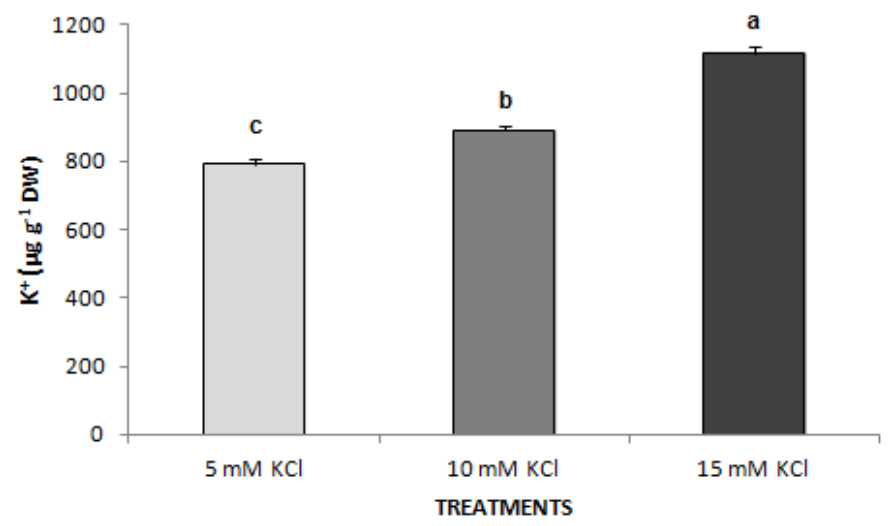

\section{Sugar metabolism}

Tomato fruit sugar content is the outcome of fruit physiological, metabolic, and genetic processes that are under developmental control (Ho and Hewitt, 1986; Baldet and al, 2006; Mounet and al, 2009; Wang and al, 
2009). Sugar production begins with leaf photosynthesis, the product of which is translocated to developing fruits. Although Suc is the main form of sugar translocated in tomato plants, Glu and Fruc are present generally in higher quantities than sucrose in tomato fruits. Among the factors that can alter the concentration of these sugars in fruits, as mentioned in the introduction, $\mathrm{K}$ availability and cold storage are notable. In our work, we found that the Suc concentration in cherry tomato fruits was not altered either by $\mathrm{K}$ treatments or by storage for 21 days at $4^{\circ} \mathrm{C}$ (Table I). On the contrary, the Gluc and Fruc concentrations increased more significantly after 21 days of storage at $4^{\circ} \mathrm{C}$ with the treatments 10 and $15 \mathrm{mM}$ de $\mathrm{KCl}$, with no appreciable variations with respect to the treatment $5 \mathrm{mM} \mathrm{KCl}$ (Table I).

Table I: Effect of $\mathrm{KCl}$ treatments at the day of harvest and after 21 days of postharvest in cold storage at $4^{\circ} \mathrm{C}$ over: sugars in cherry tomato fruits

\begin{tabular}{ccccc}
\hline \multirow{2}{*}{$\begin{array}{c}\text { KCl } \\
(\mathrm{mM})\end{array}$} & DAYS & $\begin{array}{c}\text { SACAROSE } \\
\left(\mathrm{mg} \mathrm{g}^{-1} \mathrm{FW}\right)\end{array}$ & $\begin{array}{c}\text { GLUCOSE } \\
\left(\mathrm{mg} \mathrm{g}^{-1} \mathrm{FW}\right)\end{array}$ & $\begin{array}{c}\text { FRUCTOSE } \\
\left(\mathrm{mg} \mathrm{g}^{-1} \mathrm{FW}\right)\end{array}$ \\
\hline 5 & 0 & $2.20 \pm 0.18$ & $0.96 \pm 0.13$ & $1.83 \pm 0.13$ \\
& 21 & $1.97 \pm 0.13$ & $0.86 \pm 0.11$ & $1.53 \pm 0.18$ \\
& $\begin{array}{c}\text {-value } \\
\text { LSD }\end{array}$ & $\mathrm{NS}$ & $\mathrm{NS}$ & $\mathrm{NS}$ \\
& 0.57 & 0.41 & 0.47 \\
\hline 10 & 0 & $1.65 \pm 0.16$ & $0.78 \pm 0.16 \mathrm{~b}$ & $1.91 \pm 0.19 \mathrm{~b}$ \\
& 21 & $2.03 \pm 0.29$ & $1.38 \pm 0.17 \mathrm{a}$ & $2.33 \pm 0.15 \mathrm{a}$ \\
& P-value & $\mathrm{NS}$ & $* * *$ & $*$ \\
& LSD & 0.71 & 0.49 & 0.20 \\
\hline 15 & 0 & $1.75 \pm 0.19$ & $0.69 \pm 0.11 \mathrm{~b}$ & $2.06 \pm 0.09 \mathrm{~b}$ \\
& 21 & $1.85 \pm 0.35$ & $1.34 \pm 0.05 \mathrm{a}$ & $2.33 \pm 0.05 \mathrm{a}$ \\
& $P$-value & $\mathrm{NS}$ & $*$ & $*$ \\
& LSD & 0.89 & 0.26 & 0.12 \\
\hline
\end{tabular}

Values are mean ( $n=9)$ and differences between means were compared by Fisher's leastsignificant difference test (LSD; $p=0.05$ ). Significance levels are represented by $p>0.05$, NS, not significant, ${ }^{*} p<0.05$, ${ }^{* *} p<0.01,{ }^{* * *} \mathrm{p}<0.001$. Means followed by the same letter do not differ significantly. Fresh weight (FW).

Sucrose can be converted to hexose phosphate by the ATP-dependent invertase pathway or the sucrose synthase pathway (SuSy), depending on the pyrophosphate (PPi) (Plaxton, 1996). As reflected in Table II, the neutral and acidic invertase activities diminished at $\mathrm{T} 21$ with the $5 \mathrm{mM} \mathrm{KCl}$ treatment (Table II), while for treatments 10 and $15 \mathrm{mM} \mathrm{KCl} \mathrm{no} \mathrm{variations} \mathrm{in} \mathrm{T21} \mathrm{were}$ found with respect to T0 (Table II). With respect to the SuSy activity, its response was totally contrary to that of invertase, since its activity intensified only at T21 for the treatments 10 and $15 \mathrm{mM} \mathrm{KCl}$ (Table II). In short, according to our results, we can conclude that in our work the degradation of Suc to Gluc and Fruc was due to the activity of SuSy, which was induced during postharvest at $4^{\circ} \mathrm{C}$ by the high treatments of $\mathrm{KCl}(10$ and $15 \mathrm{mM})$. 
One possible explanation for these results could be that the cold stress brings about ATP-depletion conditions (Atkin and al, 2000), which could explain the absence of participation of invertase activity in our work. The increase in Gluc and Fruc for 21 days of postharvest storage at $4^{\circ} \mathrm{C}$ in the treatments 10 and $15 \mathrm{mM} \mathrm{KCl}$ (Table I) appears to confirm the possible role of these sugars in cold resistance in tomato fruits, since, for these treatments, and especially for treatment $15 \mathrm{mM} \mathrm{KCl}$, the sugar concentration was directly correlated with the minimum reduction of fruit $\mathrm{FW}$ after 21 days of postharvest at $4^{\circ} \mathrm{C}$.

Finally, it bears highlighting two aspects that could also contribute to improving the resistance to chilling injury for the treatment $15 \mathrm{mM} \mathrm{KCl}$ : (i) the greater $\mathrm{K}$ concentration in fruits submitted to this treatment (Figure 3) could contribute, together with the accumulation of sugars (Table I), to a fall in the cellular osmotic potential and thereby to greater cold-stress resistance; and (ii) the greater Gluc accumulation in these fruits could act as a substrate for the synthesis of ascorbate, one of the early precursors in ascorbate biosynthesis (Cervilla and al, 2007), and thereby improve the antioxidant response to this type of stress, as shown Constán-Aguilar and al (2014a,b) in previous works.

Table II: Effect of $\mathrm{KCl}$ treatments at the day of harvest and after 21 days of postharvest in cold storage at $4^{\circ} \mathrm{C}$ over: sucrose synthase, neutral and acid invertases in cherry tomato fruits

\begin{tabular}{|c|c|c|c|c|}
\hline $\begin{array}{c}\mathrm{KCl} \\
(\mathrm{mM})\end{array}$ & DAYS & $\begin{array}{c}\text { NEUTRAL } \\
\text { INVERTASE } \\
\text { (mg Gluc } \text { min }^{-1} \mathrm{mg}^{-1} \\
\text { prot) }\end{array}$ & 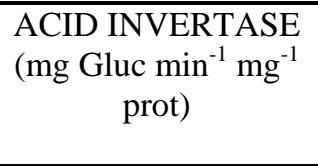 & $\begin{array}{c}\text { SuSy } \\
\left({\mathrm{mg} \mathrm{Fruc} \min ^{-1}}^{\left.\mathrm{mg}^{-1} \text { prot}\right)}\right.\end{array}$ \\
\hline \multirow[t]{4}{*}{5} & 0 & $35.37 \pm 2.33 a$ & $79.20 \pm 5.89 a$ & $49.43 \pm 5.88$ \\
\hline & 21 & $25.73 \pm 1.10 b$ & $55.33 \pm 4.89 b$ & $42.43 \pm 4.75$ \\
\hline & P-value & $* *$ & $*$ & NS \\
\hline & LSD & 7.03 & 16.68 & 9.56 \\
\hline \multirow[t]{4}{*}{10} & 0 & $35.56 \pm 1.13$ & $89.68 \pm 1.79$ & $34.69 \pm 6.38 b$ \\
\hline & 21 & $36.69 \pm 1.49$ & $91.30 \pm 2.24$ & $43.83 \pm 9.13^{\mathrm{a}}$ \\
\hline & P-value & NS & NS & $*$ \\
\hline & LSD & 3.96 & 6.07 & 7.97 \\
\hline \multirow[t]{4}{*}{15} & 0 & $39.99 \pm 0.58$ & $100.22 \pm 2.27$ & $52.11 \pm 7.68 b$ \\
\hline & 21 & $36.58 \pm 0.40$ & $85.75 \pm 1.52$ & $55.48 \pm 3.83^{\mathrm{a}}$ \\
\hline & P-value & NS & NS & $*$ \\
\hline & LSD & 3.49 & 15.78 & 2.91 \\
\hline
\end{tabular}

Values are mean $(n=9)$ and differences between means were compared by Fisher's leastsignificant difference test (LSD; $p=0.05$ ). Significance levels are represented by $p>0.05$, NS, not significant, ${ }^{*} p<0.05,{ }^{* *} p<0.01,{ }^{* * *} p<0.001$. Means followed by the same letter do not differ significantly. 


\section{Organic acid metabolism}

The TCA cycle connects glycolysis to amino acid biosynthesis and is important in the regulation of respiration and energy generation by producing ATP and NADH. In fruit, the TCA cycle is involved in organic acid biosynthesis, but little information is available on the dynamics of tricarboxylic acid cycle (TCA)-related metabolism.

With respect to the organic acids malate and citrate, Figure 4A $(P<0.05)$ shows how with the treatment $5 \mathrm{mM} \mathrm{KCl}, 21$ days postharvest at $4^{\circ} \mathrm{C}$, malate significantly diminished. On the contrary, the application of 10 and $15 \mathrm{mM}$ of $\mathrm{KCl}$ increased this organic acid at T21 with respect to T0 (Figure 4A). Citric acid, independently of the $\mathrm{K}$ treatment applied during storage for 21 days at $4^{\circ} \mathrm{C}$, prompted a significant decline in this organic acid (Figure 4B, $P<0.05$ ).

The response in our work of the different concentrations in cherry tomato fruit of malic and citric acid can be explained by the activities of PEPC, MDH, and CS. Table III shows that, due to the PEPC activity, cold storage for 21 days resulted in a decline in the activity with the treatment 5 $\mathrm{mM} \mathrm{KCl}$ (Table III), which, together with the increased MDH activity (Table III) at T21 indicated that the tricarboxylic acid cycle was functioning in the sense that $\mathrm{MDH}$ degrades malate to form oxaloacetate. This could have been accumulating, since the CS activity fell in this treatment (Table III). In short, the behaviour of these enzymes would explain the decline in the treatment 5 $\mathrm{mM}$ de $\mathrm{KCl}$ of the malic and citric acid concentrations at T21 (Figures 4A and $4 \mathrm{~B}$ ). However, with the treatments 10 and $15 \mathrm{mM}$ of $\mathrm{KCl}$, high PEPC and MDH activity at T21 (Table III) would explain why malate increased, since $\mathrm{MDH}$ would be converted oxaloacetate generated from PEPC into malate. Therefore, in these treatments, the synthesis of this organic acid could be occurring by the anaplerotic pathway. The accumulation of malate in the treatments 10 and $15 \mathrm{mM}$ at T21 could also be explained by the behaviour of the CS activity in these treatments, since in none of them significantly stimulated this enzymatic activity at T21 ( Table III). 
Figure 4: Effect of $\mathrm{KCl}$ treatments at the day of harvest and after 21 days of postharvest in cold storage at $4{ }^{\circ} \mathrm{C}$ over: malic acid and citric acid in cherry tomato fruits. Values are means $(n=9)$ and differences between means were compared by Fisher's least-significant difference test of (LSD, $p=0.05$ ). Means followed by the same letter do not differ significantly.
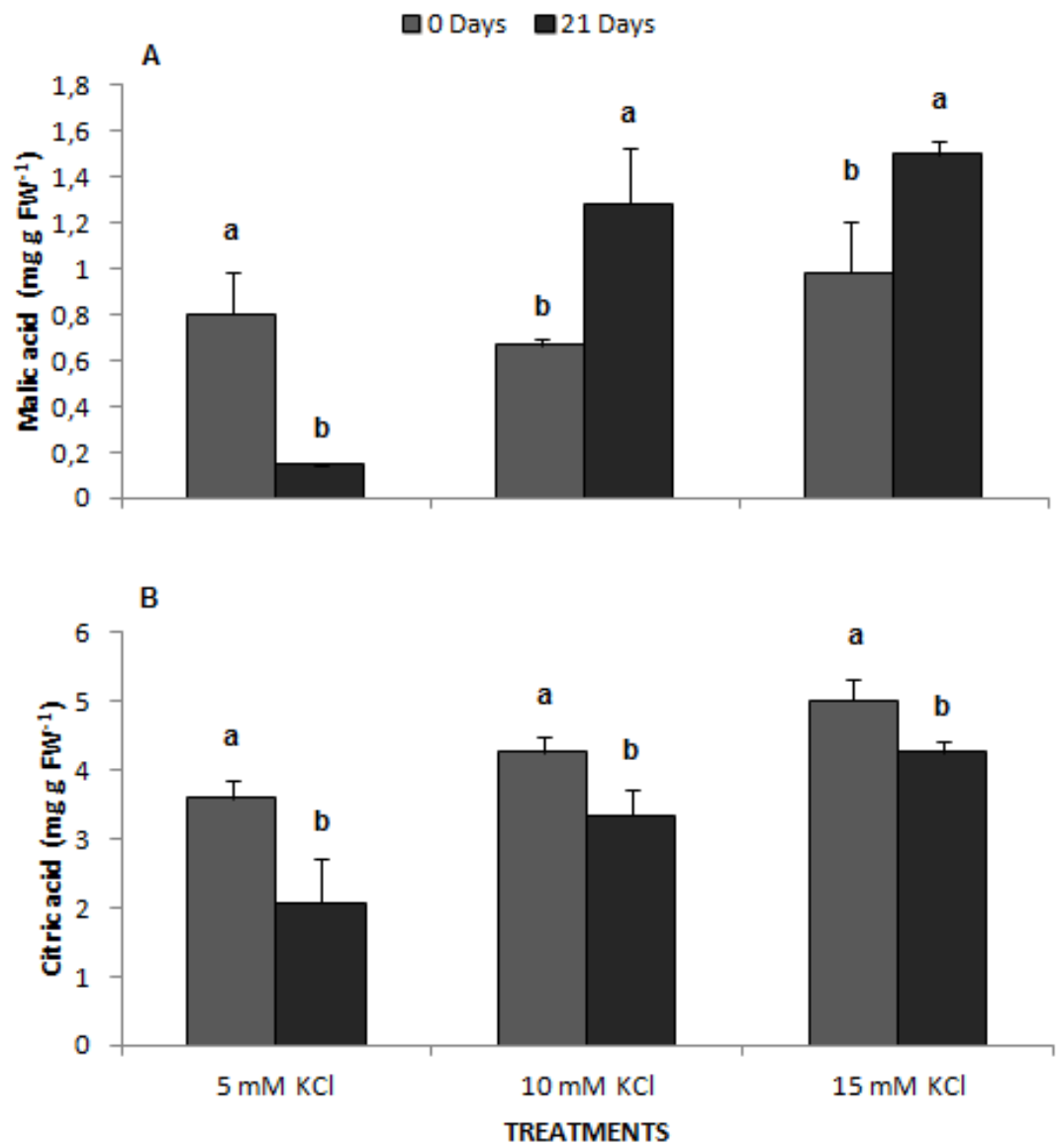
Table III: Effect of $\mathrm{KCl}$ treatments at the day of harvest and after 21 days of postharvest in cold storage at $4^{\circ} \mathrm{C}$ over: PEPC, MDH, CS in cherry tomato fruits

\begin{tabular}{|c|c|c|c|c|}
\hline $\begin{array}{c}\mathrm{KCl} \\
(\mathrm{mM})\end{array}$ & DAYS & $\begin{array}{c}\text { PEPC } \\
\left(\triangle \text { Abs hour }^{-1} \mathrm{mg}^{-1}\right. \\
\text { prot })\end{array}$ & $\begin{array}{c}\text { MDH } \\
\left(\Delta \text { Abs hour }^{-1} \mathrm{mg}^{-1}\right. \\
\text { prot })\end{array}$ & $\begin{array}{c}\mathrm{CS} \\
(\Delta \mathrm{Abs} \text { hour } \\
\text { prot })\end{array}$ \\
\hline \multirow[t]{4}{*}{5} & 0 & $1.61 \pm 0.20 \mathrm{a}$ & $1.07 \pm 0.20 \mathrm{~b}$ & $0.63 \pm 0.13 a$ \\
\hline & 21 & $0.12 \pm 0.03 \mathrm{~b}$ & $3.07 \pm 0.18 \mathrm{a}$ & $0.30 \pm 0.04 b$ \\
\hline & $P$-value & $* *$ & $* * *$ & $* *$ \\
\hline & LSD & 0.71 & 0.74 & 0.15 \\
\hline \multirow[t]{4}{*}{10} & 0 & $1.21 \pm 0.08 b$ & $1.81 \pm 0.50 \mathrm{~b}$ & $0.95 \pm 0.04 a$ \\
\hline & 21 & $2.97 \pm 0.67 a$ & $3.41 \pm 0.03 a$ & $0.73 \pm 0.00 \mathrm{~b}$ \\
\hline & P-value & $* *$ & $*$ & $* *$ \\
\hline & LSD & 0.57 & 1.39 & 0.12 \\
\hline \multirow[t]{4}{*}{15} & 0 & $0.34 \pm 0.22 b$ & $4.26 \pm 0.62 b$ & $0.81 \pm 0.21$ \\
\hline & 21 & $1.06 \pm 0.04 \mathrm{a}$ & $8.64 \pm 1.13 a$ & $1.12 \pm 0.33$ \\
\hline & $P$-value & $*$ & $*$ & NS \\
\hline & LSD & 0.61 & 3.57 & 1.09 \\
\hline
\end{tabular}

Values are mean $(n=9)$ and differences between means were compared by Fisher's leastsignificant difference test (LSD; $p=0.05$ ). Significance levels are represented by $p>0.05$, NS, not significant, ${ }^{*} p<0.05,{ }^{* *} p<0.01,{ }^{* * *} p<0.001$. Means followed by the same letter do not differ significantly.

\section{Sweetness index}

The sweetness index is a parameter frequently used in many fruits to describe their flavour and commercial acceptability (Keutgen and Pawelzik, 2008). In our work, with regard to the sugar:acid ratio, the postharvest cold storage for 21 days for the $5 \mathrm{mM} \mathrm{KCl}$ treatment diminished this index with respect to that of T0 $(P<0.05$, Figure 5$)$. On the contrary, the treatments 10 and $15 \mathrm{mM} \mathrm{KCl}$, after the cold-storage period showed a rise in this index at T21 $(P<0.05$, Figure 5), indicating that the treatments $\mathrm{K}$ increased the sugar involved in the determination of this index after the postharvest, and therefore improved the likelihood of customer acceptance. 
Figure 5: Effect of $\mathrm{KCl}$ treatments at the day of harvest and after 21 days of postharvest in cold storage at $4^{\circ} \mathrm{C}$ over: Sweetness index in cherry tomato fruits. Values are means $(n=9)$ and differences between means were compared by Fisher's least-significant difference test of (LSD, $p=0.05$ ). Means followed by the same letter do not differ significantly.

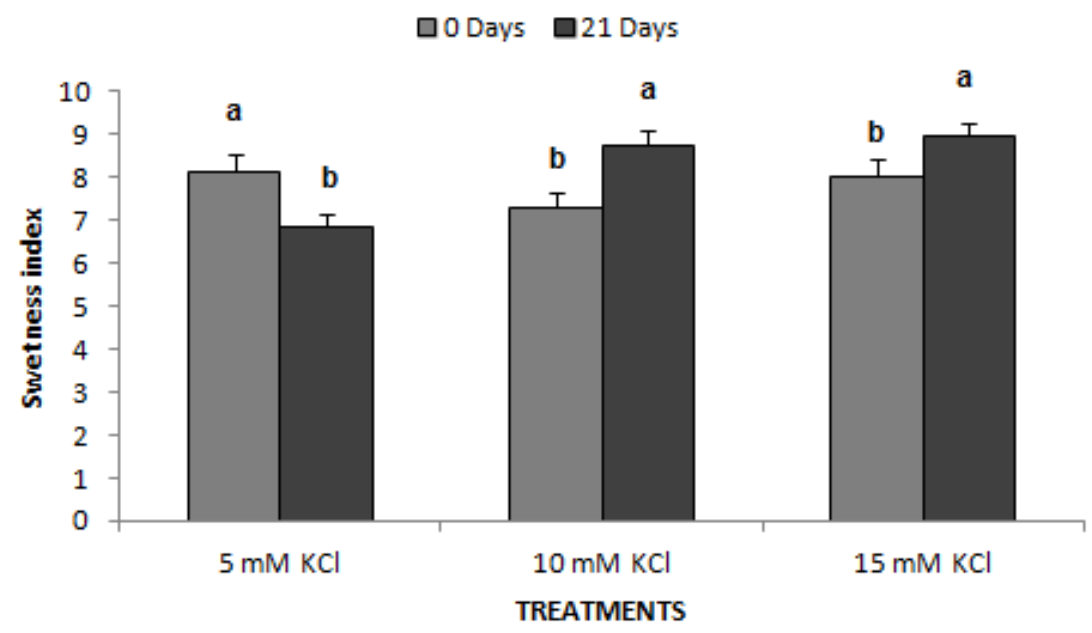

\section{Conclusion}

Application of a biofortification programme with $\mathrm{K}$, increasing the application rates of this nutrient in the nutrient solution during tomato cultivation, improved the fruit response to postharvest storage at $4^{\circ} \mathrm{C}$ for 21 days. This improved response was found in our work at $10 \mathrm{mM}$ and specifically with the rate of $15 \mathrm{mM}$ of $\mathrm{KCl}$, and this could be related to changes in the carbon metabolism. Thus, the application of high amounts of $\mathrm{K}$, in addition to increasing the concentration of this nutrient in fruits, stimulated the Suc degradation by SuSy activity, raising the levels of Glu and Fruc and inducing the accumulation of malate by the activity of the enzymes PEPC and MDH during storage for 21 days at $4^{\circ} \mathrm{C}$. Therefore, in our work the accumulation of Glu, Fruc, and malate could explain the protective role, during cold storage, of the treatment $15 \mathrm{mM}$ of $\mathrm{KCl}$, showing the minimum reduction of the \% LFW. Finally, it bears indicating that the implementation of biofortification programmes with high rates of $K$ application (in our case 10 and $15 \mathrm{mM}$ of $\mathrm{KCl}$ ) clearly improves the organoleptic quality of cherry tomato fruits during postharvest at $4^{\circ} \mathrm{C}$, with an increase in the sweetness index. In addition, the consumption of these fruits provides added intake of this element as a potential benefit to human health.

\section{Acknowledgments}

This work was supported by Instituto Nacional de Investigación y Tecnología Agraria y Alimentaria (INIA). Project RTA2009-00005-00-00 
cofinanced by the European Union through FEDER funds and was carried out at Instituto Andaluz de Investigación y Formación Agraria, Pesquera, Alimentaria y de la Producción Ecológica in Granada, Spain (IFAPA) and the AGR161 research group.

\section{References:}

Almeselmani, M., Pant, R. C., \& Singh B. (2010). Potassium level and physiological response and fruit quality in hydroponically grown tomato. International Journal of Vegetable Science, 16, 85-99.

Atkin, O. K., Edwards, E. J. \& Loveys, B. R. (2000). Response of root respiration to changes in temperature and its relevance to global warming. New Phytologist, 147, 141-154.

Baldet, P., Hernould, M., Laporte, F., Mounet, F., Just, D., Mouras, A., Chevalier, C. \& Rothan, C. (2006). The expression of cell proliferationrelated genes in early developing flowers is affected by a fruit load reduction in tomato plants. Journal of Experimental Botany, 57, 961-970.

Balibrea, M. E., Santa-Cruz, A. M., Bolarín, M. C. \& Pérez-Alfocea, F. (1996). Sucrolytic activities in relation to sink strength and carbohydrate composition in tomato fruit growing under salinity. Plant Science, 118, 4755.

Baxter, C.J., Sabar, M., Quick, W. P. \& Sweetlove, L. J. (2005). Comparison of changes in fruit gene expression in tomato introgression lines provides evidence of genome-wide transcriptional changes and reveals links to mapped QTLs and described traits. Journal of Experimental Botany, 56, 1591-1604.

Ben-Yehoshua, S. \& Rodov, V. (2003). Transpiration and water stress. In: Bartz J. A. \& Brecht, J. K. (eds.) Postharvest physiology and pathology of vegetables. Marcel Dekker, New York, pp 111-159.

Beringer, H. \& Trolldenier, G. (1980). The influence of K nutrition on the response of plants to environmental stress. Potassium Research-Review and Trends, Proc. llth Congress of the International Potash Institute, Bern, Switzerland, September 4-8, pp.189-222.

Bilton, R., Gerber, M., Grolier, P. \& Leoni, C. (2001). The White Book on Antioxidants in Tomatoes and Tomato Products and Their Health Benefits; Final report of the Concerted Action Fair CT97-3233. CMITI Sarl, Avignon. Bucheli, P., Voirol, E., de la Torre, R., López, J., Rytz, A., Tanksley, S. D. \& Pétiard, V. (1999). Definition of nonvolatile markers for flavor of tomato (Lycopersicon esculentum Mill.) as tools in selection and breeding. Journal of Agricultural and Food Chemistry, 47, 659-664.

Cao, S., Yang, Z. \& Zheng, Y. (2013). Sugar metabolism in relation to chilling tolerance of loquat fruit. Food Chemistry, 136, 139-143. 
Carrari, F., Baxter, C., Usadel, B., Urbanczyk-Wochniak, E., Zanor, M. I., Nunes-Nesi, A., Nikiforova, V., Centero, D., Ratzka, A., Pauly, M., Sweetlove, L. J. \& Fernie, A. R. (2006). Integrated analysis of metabolite and transcript levels reveals the metabolic shifts that underlie tomato fruit development and highlight regulatory aspects of metabolic network behavior. Plant Physiology, 142, 1380-1396.

Causse, M., Saliba-Colombani, V., Lecomte, L., Duffé, P., Rousselle, P. \& Buret, M. (2002). QTL analysis of fruit quality in fresh market tomato: a few chromosome regions control the variation of sensory and instrumental traits. Journal of Experimental Botany, 53, 2089-2098.

Cervilla, L. M., Blasco, B., Ríos, J. J., Romero, L., Ruiz, J. M. (2007). Oxidative stress and antioxidants in tomato (Solanum lycopersicum) plants subjected to boron toxicity. Annals of Botany, 100, 747-756.

Cheikh, N. \& Brenner, M. L. (1992). Regulation of key enzymes of sucrose biosynthesis in soybean leaves. Effect of dark and light conditions and role of gibberellins and abscisic acid. Plant Physiology, 100, 1230-1237.

Constán-Aguilar, C., Leyva, R., Blasco, B., Sánchez-Rodríguez, E., Soriano, T. \& Ruiz, J. M. (2014a). Biofortification with potassium: antioxidant responses during postharvest of cherry tomato fruits in cold storage. Acta Physiologiae Plantarum, 36, 283-293.

Constán-Aguilar, C., Leyva, R., Romero, L., Soriano, T. \& Ruiz, J. M. (2014b). Implication of potassium on the quality of cherry tomato fruits after postharvest during cold storage. International Journal of Food Sciences and Nutrition, 65, 203-211.

Constán-Aguilar, C., Leyva, R., Romero, L., Soriano, T., Blasco, B. \& Ruiz, J. M. (2015). The effect of potassium biofortification over yield and nutritional quality of cherry tomato fruits. American Journal of Advanced Food Science and Technology, 3, 67-93.

Dannel, F., Pfeffer, H. \& Marschner, H. (1995). Isolation of apoplasmic fluid from sunflower leaves and its use for studies on influence of nitrogen supply on apoplasmic pH. Journal of Plant Physiology, 50, 208-213.

Davies, J. N. \& Hobson, G. E. (1981). The constituents of tomato fruit-the influence of environment, nutrition, and genotype. CRC Critical Reviews in Food Science and Nutrition, 15, 205-280.

Doehlert, D. C. \& Chourey, P. S. (1991). Possible roles of sucrose synthase in sink function. In: Bonnemain, J. L., Delrot, S., Lucas, W. J. \& Dainty, J. (eds.), Recent Advances in Phloem Transport and Assimilate Compartmentation. Ouest Editions, Nantes, pp. 187-195.

Farneti, B., Zhang, W., Witkowska, I. \& Woltering, E. J. (2010). Effect of home-refrigerator storage temperature on tomato quality. Acta Horticulturae, 877, 1191-1196. 
García-Closas, R., Berenguer, A., Tormo, M. J., Sánchez, M. J., Quirós, J. R., Navarro, C., Arnaud, R., Dorronsoro, M., Chirlaque, M.D., Barricarte, A., Ardanaz, E., Amiano, P., Martínez, C., Agudo, A. \& González, C. A. (2004). Dietary sources of vitamin C, vitamin E and especific carotenoids in Spain. British Journal of Nutrition, 91, 1005-1011.

Garg, N. \& Cheema, D. S. (2011). Assessment of fruit quality attributes of tomato hybrids involving ripening mutants under high temperature conditions. Scientia Horticulturae, 131, 29-38.

Geiger, D., Koch, K. \& Shieh, W. (1996). Effect of environmental factors on whole plant assimilate partitioning and associated gene expression. Journal of Experimental Botany, 47, 1229-1238.

Gomez, P., Ferrer, M. A., Fernandez-Trujillo, J. P., Calderon, A., Artes, F., Egea-Cortines, M. \& Weiss, J. (2009). Structural changes, chemical composition and antioxidant activity of cherry tomato fruits (cv Micro-Tom) stored under optimal and chilling conditions. Journal of Science and Food Agriculture, 89, 1543-1551.

González-Aguilar, G. A., Tiznado-Hernández, M. E., Savaleta-Gatica, R. \& Martineze, M. A. (2004). Methyl jasmonate treatments reduce chilling injury and activate the defense response of guava fruits. Biochemical and Biophysical Research Communications, 313, 694-701.

Gough, C. \& Hobson, G. E. (1990). A comparison of the productivity, quality, shelf-life characteristics and consumer reaction to the crop from cherry tomato plants grown at different levels of salinity. Journal of Horticultural Science, 65, 431-439.

Guillet, C., Just, D., Bénard, N., Destrac-Irvine, A., Baldet, P., Hernould, M., Causse, M., Raymond, P. \& Rothan, C. (2002). A fruit-specific phosphoenolpyruvate carboxylase is related to rapid growth of tomato fruit. Planta, 214,717-726.

Hakerlerler, H., Oktay, M., Eryüce, N. \& Yagmur, B. (1997). Effect of potassium sources on the chilling tolerance of some vegetable seedlings grown in hotbeds, in Johnston, A. E. Food Security in the WANA Region, the Essential Need for Balanced Fertilization. International Potash Institute, Basel, pp. 317-327.

Han, Q., Jiang, W., Yu, H. \& Wang, M. (2012). Effects of potash applied at different growth phases on tomato yield and quality in greenhouse. Acta Horticulturae, 944, 45-50.

He, F. J. \& MacGregor, G. A. (2008). Beneficial effects of potassium on human health. Physiologia Plantarum, 133, 725-735.

Ho, L. C. \& Hewitt, J. D. (1986). Fruit Development. In: Atherton, J. G. \& Rudich, J. (Eds.). The Tomato Crop. Chapman and Hall, New York, pp. 201-240. 
Hubbard, N.L., Huber, S. C. \& Pharr, D. M. (1989). Sucrose phosphate synthase and acid invertase as determinants of sucrose concentration in developing muskmelon (Cucumis melo L.) fruits. Plant Physiology, 91, 1527-1534.

Javaria, S., Khan, M. Q. \& Bakhsh, I. (2012). Effect of potassium on chemical and sensory attributes of tomato fruit. Journal of Animal and Plant Sciences, 22, 1081-1085.

Kafkafi, U. (1990). The functions of plant $\mathrm{K}$ in overcoming environmental stress situations. In: Development of K-fertilizer recommendations: proceedings 22nd Colloquium of the International Potash Institute, pp. 8193.

Kerr, P. S., Huber, S. C. \& Israel, D. W. (1984). Effect of N-source on soybean leaf sucrose phosphate synthase, starch formation, and whole plant growth. Plant Physiology, 75, 483-488.

Keutgen, A. J. \& Pawelzik, E. (2008). Quality and nutritional value of strawberry fruit under long term salt stress. Food Chemistry, 107, 14131420.

Liu, H. F., Génard, M., Guichard, S. \& Bertin, N. (2007). Model-assisted analysis of tomato fruit growth in relation to carbon and water fluxes. Journal of Experimental Botany, 58, 3567-3580.

Lobit, P., Génard, M., Wu, B. H., Soing, P. \& Habib, R. (2003). Modelling citrate metabolism in fruits: Responses to growth and temperature. Journal of Experimental Botany, 54, 2489-2501.

López-Millán, A. F., Morales, F., Abadía, A. \& Abadía, J. (2001). Changes induced by Fe deficiency and Fe resupply in the organic acid metabolism of sugar beet (Beta vulgaris) leaves. Physiologia Plantarum, 112, 31-38.

Mounet, F., Moing, A., Garcia, V., Petit, J., Maucourt, M., Deborde, C., Bernillon, S., Le Gall, G., Colquhoun, I., Defernez, M., Giraudel, J. L., Rolin, D., Rothan, C. \& Lemaire-Chamley, M. (2009). Gene and metabolite regulatory network analysis of early developing fruit tissues highlights new candidate genes for the control of tomato fruit composition and development. Plant Physiology, 149, 1505-1528.

Plaxton, W. C. (1996). The organization and regulation of plant glycolysis. Annual Review of Plant Physiology and Plant Molecular Biology, 47, 185214.

Rosales, M. A., Rubio-Wilhelmi, M. M., Castellano, R., Castilla, N., Ruiz, J. M. \& Romero, L. (2007). Sucrolytic activities in cherry tomato fruits in relation to temperature and solar radiation. Scientia Horticulturae, 113, 244 249.

Sadka, A., Artzi, B., Cohen, L., Dahan, E., Hasdai, D., Tagari, E. \& Erner, Y. (2000). Arsenite reduces acid content in citrus fruit, inhibits activity of 
citrate synthase but induces its gene expression. Journal of American Society of Horticultural Science, 125, 288-293.

Salles, C., Nicklaus, S. \& Septier, C. (2003). Determination and gustatory properties of taste-active compounds in tomato juice. Food Chemistry, 81, 395-402.

Sánchez-Bel, P., Egea, I., Sánchez-Ballesta, M. T., Martinez-Madrid, C., Fernandez-Garcia, N., Romojaro, F., Olmos, E., Estrella, E., Bolarín, M. C. \& Flores, F. B. (2012). Understanding the mechanisms of chilling injury in bell pepper fruits using the proteomic approach. Journal of Proteomics, 75, 5463-5478.

Schauer, N., Zamir, D. \& Fernie, A. R. (2005). Metabolic profiling of leaves and fruit of wild species tomato: a survey of the Solanum lycopersicum complex. Journal of Experimental Botany, 56, 297-307.

Scherer, R., Rybka, A. C. P., Ballus, C.A., Meinhart, A.D., Filho, J.T. \& Godoy, H.T. (2012). Validation of a HPLC method for simultaneous determination of main organic acids in fruits and juices. Food Chemistry, 135, 150-154.

Soriano, T., Montero, J. I., Sánchez-Guerrero, M. C., Medrano, E., Antón, A., Hernández, J., Morales, M. I. \& Castilla, N. (2004). A study of direct solar radiation transmission in asymmetrical multi-span greenhouses using scale models and simulation models. Biosystem Enginering, 88, 243-253. Srere, P. A. (1967). Citrate synthase. Methods in Enzymology, 13, 3-11. Steinhauser, M. C., Steinhauser, D., Koehl, K., Carrari, F., Gibon, Y., Fernie, A. R. \& Stitt, M. (2010). Enzyme activity profiles during fruit development in tomato cultivars and Solanum pennellii. Plant Physiology, 153, 80-98.

Wang, H., Schauer, N., Usadel, B., Frasse, P., Zouine, M., Hernould, M., Latché, A., Pech, J. C., Fernie, A. R. \& Bouzayen, M. (2009). Regulatory features underlying pollination-dependent and -independent tomato fruit set revealed by transcript and primary metabolite profiling. Plant Cell, 21, $1428-1452$.

Wolf, B. (1982). A comprehensive system of leaf analysis and its use for diagnosing crop nutrient status. Communications in Soil Science and Plant Analysis, 13, 1035-1059.

Yermiyahu, U. \& Kafkafi, U. (1990). Yield increase and stem brittle decrease in response to increasing concentrations of potassium and $\mathrm{NO}_{3}{ }^{-}$ $/ \mathrm{NH}_{4}{ }^{-}$in White Carnation cv. Standard. Hassadeh, 90, 742-746. 